\title{
Videoactivism and Construction of Mediatic Identities, YouTube and \#YoSoy132*
}

\author{
Salomé Sola-Morales ** \\ Received: 2019-02 15 - Sent to peers: 2019-02-20 \\ Approved by peers: 2019-03-28 - Acepted: 2019-05-20 \\ https://doi.org/10.22395/angr.v18n35a2
}

\begin{abstract}
Abtract
The main goal of this paper is to analyze \#YoSoy 132 construction of mediatic identities through videoactivism, and to question if YouTube was determinant or simply instrumental in the implosion of the movement. During the 2012 "Mexican Spring", students and citizens not only occupied the streets to quest for a "real democracy" or to express their dissent through very significant demonstrations, but they also occupied the internet to protest. First of all, identity features of the movement are analyzed in relation with the following variables: 1) nucleus of belonging, 2) main sociodemographic features, 3) forms of leadership, 4) interests, 5) collective identity, and 6) relationship with otherness. Second, through a qualitative methodology — content analysis—, this paper analyzes the most relevant pieces of videoactivism produced by young adults. This study focused on the role and function of the videos to know if social media was "instrumental" or "determinant". Third, mediatic identities represented in the videos are analyzed by exploring the following aspects: a) protagonists appearing in the videos: main role, gender and age range, b) locations where these characters appear and c) type of identity represented: hegemonic or counter-hegemonic, majority or minority. The main result of this research is that a resistence and contra-hegemonic identity is created through YouTube videos by young Mexicans. Moreover, being \#YoSoy 132 goes far beyond being young, student or belonging to a specific university. In this regard, the scenario is not occupied by a single subject or specific group of people, but it belongs to the "oppressed" and to persons at risk or discrimination.
\end{abstract}

Keywords: \#YoSoy 132; mediatic identities; youtube; videoactivism; online mobilizations.

This paper was written in the framework of a Project entitled: "Youth Chilean Participation in Democratic Life. Impact of New Media", code 031496SM, funded by the Direction of Scientific and Technologic Research (Dicyt), from the Vicechair of Research, Development and Innovation from the University of Santiago de Chile, Chile, from which the author was the main researcher. Project developed from March 2014 until March 2016.

* Ph.D. in Media, Communication and Culture, Universidad Autónoma de Barcelona (aub). MA in Politics and Democracy, Universidad Nacional de Educación a Distancia (Uned). Researcher in the Communication, Politics and Social Change (Compolíticas) interdisciplinary group, Honorary Assistant in the Journalism Department 1 at Universidad de Sevilla. She has been Associated Professor and Research Coordinator in the Universidad de Santiago de Chile; and Assistant Professor at International University of Catalonia, Spain, and at AUB (Spain). Visiting Professor at Universidad Complutense de Madrid (Spain). Her papers and essays on identity, body, politics and their relationship with the media have been published in journals such as Culture, Language and Representation, Doxa Communication, IC Journal, History and Social Communication, Mediaciones Sociales, Tabula Rasa, Chasqui, Athenea, Poliantea, Estudos em Comunicaçao, Ars Brevis or Cinta de Moebio and by publishers, such as Peter Lang and Praeger/ABC-CLIO California. Her H-Index is 5. Correo electrónico: ssolamorales@gmail.com. Orcid: http://orcid.org/0000-0001-7085-4595 


\title{
Videoactivismo y construcción de identidades mediáticas, YouTube y \#YoSoy 132
}

\begin{abstract}
Resumen
El objetivo principal de este artículo es analizar la construcción de la identidad mediática a través del video activismo del \#yosoy132 y cuestionar si YouTube fue determinante o simplemente instrumental en la implosión del movimiento. Durante la "primavera mexicana" del 2012, los estudiantes y demás ciudadanos no solo ocuparon las calles para pedir una "democracia real" o para expresar su disenso a través de manifestaciones muy significativas, sino que también ocuparon la internet para protestar. En primer lugar, las características del movimiento son analizadas desde su relación con las siguientes variables: 1) núcleo de pertenencia, 2)características socio demográficas principales, 3) formas de liderazgo, 4) intereses, 5) identidad colectiva, y 6) relación con la otredad. En segundo lugar, a través de una metodología cualitativa —análisis de contenido-, este artículo analiza las piezas de video activismo más representativas producidas por jóvenes adultos. Este estudio se enfoca en el rol y la función de los videos para saber si las piezas mediáticas sociales fueron "instrumentales" o "determinantes". En tercer lugar, las identidades mediáticas presentadas en los videos son analizadas desde los siguientes aspectos: a) protagonistas en los videos: rol principal, género y rango etario, b) locaciones en las que estos personajes aparecen y c) tipo de la identidad representada: hegemónica o contra-hegemónica, mayoría o minoría. El resultado principal de esta investigación es que la resistencia y la identidad contra-hegemónica es creada a partir de videos de YouTube hechos por jóvenes mexicanos. Más aún, teniendo en cuenta que \#YoSoy 132 trasciende el hecho de ser joven, estudiante o de pertenecer a una universidad específica. A este respecto, el escenario no es ocupado por un sujeto específico o un grupo específico de personas, sino que perteneces a los "oprimidos" y a las persones en riesgo o discriminadas.
\end{abstract}

Palabras clave: \#YoSoy 132; Identidades Mediáticas; YouTube; Videoactivismo; Movilizaciones en línea.

\section{Videoativismo e construção de identidades midiáticas, YouTube e \#YoSoy132}

\section{Resumo}

O principal objetivo deste artigo é analisar o \#YoSoy132 e a construção de identidades midiáticas por meio do videoativismo e questionar se o YouTube foi determinante ou simplesmente instrumental na implosão do movimento. Durante a "Primavera Mexicana" de 2012, estudantes e cidadãos não só ocuparam as ruas para pedir a "real democracia" ou para expressar sua discordância por meio de manifestações bastante significativas, mas eles também ocuparam a internet para protestar. Primeiramente, as características identitárias do movimento são analisadas com respeito às seguintes variáveis: 1) núcleo de pertencimento, 2) principais características sociodemográficas, 3) formas de liderança, 4) interesses, 5) identidade coletiva e 6) relação com a alteridade. Em segundo lugar, por meio de uma metodologia qualitativa - análise de conteúdo - , este artigo analisa os trabalhos de videoativismo mais relevantes produzidos por jovens adultos. O presente estudo se concentra no papel e na função de vídeos para saber se as mídias sociais foram "instrumentais" ou "determinantes". Em terceiro lugar, as identidades midiáticas representadas nos vídeos são analisadas ao explorar os seguintes aspectos: a) protagonistas que aparecem nos vídeos - papel principal, gênero e faixa etária, b) locais onde esses personagens aparecem e c) tipo de identidade representada - hegemônica ou contra hegemônica, maioria ou minoria. O principal resultado desta pesquisa é que uma identidade contra hegemônica e de resistência é criada por meio de vídeos do YouTube por jovens mexicanos. Sobretudo, ser \#YoSoy 132 vai muito além de ser jovem, estudante ou pertencer a uma universidade específica. Nesse sentido, o cenário não é ocupado por um único sujeito ou por um grupo específico de pessoas, mas pertence aos "oprimidos" e às pessoas em risco ou que sofrem discriminação.

Palavras-chave: \#YoSoy 132; identidades midiáticas; YouTube; videoativismo; mobilizações online. 


\section{Introduction}

Over the last decades, digital technology has started to transform political life (Chadwick 2013; Cotarelo \& Crespo, 2012). Thus, internet and social media have an important impact in democracy (Hacker $\&$ Van Dijk 2000). Despite some researchers claim that internet is overstated (Gladwell 2010; Weyland, 2012), the truth is that the massive use of social media by youth is leading a debate on the key role of technology in cyberactivism (Banaji \& Buckinjam, 2010; Carty \& Reynoso Barron, 2019; Colombo Villarrasa, 2007; Cotarelo \& Crespo, 2012; Coombs, 2009; Chamberlain, 2004; García Galera \& Hurtado, 2013; Gerodimos, 2010; Karakaya, 2005; Khamis E Alwadi, 2015; Khamis, 2017; McCaughey, 2014; Mccaughey E Ayers, 2003; Sampedro, 2011; Sandoval-Almazan \& Gil-García, 2014; Shadrin, 2000, asi cited in Rudenko, 2009; Sierra Caballero, 2018; Sirkkunen \& Kotilainen, 2004; Ugarte, 2007; Ward, 2005). That is especially with regard to the promotion of youth political participation and engagement. Moreover, in the development of student and social movements (Barassi E Treré, 2012; Breuer, 2012; Gerbaudo, 2012; Hussain \& Howard, 2013; Mattoni, 2012; McCurdy, 2011; Treré, 2012; 2015).

Some political dissenting experiences, in the last two decades around the world have given rise to new practices of digital activism (such as social movement's communication strategies, organization and collective action). In that vein, activism in the Internet Age (Earl \& Kimport, 2011) has been established nowadays as a common feature of movements such as Anonymous, the Arab Spring, the Spanish 15M, the Mexican \#Yosoy132, the Geração à rasca in Portugal, the Free Pass Movement in Brazil, the Occupy, the Penguin Revolution and the Chilean Spring, or more classical movements like the French Gillet Jaunes. All these experiences give a good account on technopolitics' importance today (Sierra \& Gravante, 2017) today and have shown that social media are fundamental in "recent social movements" (Sabariego, 2017; 2018) development.

However, the relationship between social movements and the internet can either be "determinant" or "instrumental" (Welp, 2015), focused on a social network (Facebook, Instragram, YouTube or Twitter, for instance), the combination of several of them, or develop more elaborate forms of videoactivism.

Videoactivism is a social, audiovisual practice of a communicative nature, used as a resource for political intervention by actors outside the dominant power structures, with an aim of transformation and social change (Mateos \& Rajas, 2014; Mateos \& Gaona, 2015; Montero \& Candón, 2015; Montero \& Sierra, 2017; Sierra \& Montero, 2016). These types of actions have the capacity to challenge public opinion (Brisset, 2011; Dodaro, 2009) and can be key to defining the political agenda, articulating social movements or denouncing attitudes of little solidarity (Sierra \& Montero, 2015). Analyzing 
these communicative practices is fundamental when addressing the communication of social movements and understanding the new logics of connective action (Bennett E Segerberg, 2012; 2013; Castells, 2009; Cammaerts, 2012; Earl \& Kimport, 2011; Juris, 2012; Vaast et al., 2017).

During 2012 Mexican students expressed their dissent throught digital media and organised important demonstrations in Mexico. One of the things that makes this social movement more interesting was the use of Internet and social media and particularly, the use of YouTube as an intrument for change and transformation. In fact, the Mexican case is paradigmatic and therefore fundamentally to be analyzed it in depth.

Young people played a leading role in the discusion over media and over the need to make a "real democracy". In order to protest against the government and to change Mexican audiovisual system, students became directors and producers of short-films that went viral in YouTube. While other social media as Facebook or Twitter were mainly used to organize protest actions, to describe the achievements of the movement, or to point out the opponents, YouTube videos became a key identitary tool that impulse political participation. In that particular case videoactivism (Sierra \& Montero, 2015) located the student's claims closer to the rest of the citizenship.

\#YoSoy132, as many of the so called "new social movements", has a high identitary and cultural component. One of its basic features could be its student profile. In that sense, student body or age cohort should be the main signs of belonging. Nevertheless, even though youth is one of its key features, the movement's has adopted a much broader scope and involved many more far resistance identities. In a first instance, students were the main characters. However, with the movement's development, referents were extended to a big part of citizenship. In this area of tensions, contradictions, virtual and street protests between citizenship and institutionalism, social actors are the key of colective action. In this way, the reference axis — called membership or community - moves from an economic to a cultural or identitary one.

This paper's main goal is to analyze \#YoSoyl32 construction of mediatic identities through videoactivism, and to question if YouTube was determinant or simply instrumental in the implosion of the movement.

\section{Characteristics and context of the Mexican \#132 Movement}

The intervention of Peña Nieto as presidential candidate at Universidad Iberoamericana on May 11th, 2012, in relation to the Atenco Riots of 2006, where several murders and numerous violations of Human Rights were committed by the police, was the conjuncture that imploded the Mexican student movement \#YoSoy132. That speech was the starting signal of unleashed anger at the structural crisis and the accumulation of 
malaise that had been afflicting Mexico for years. Thus, it can be said that the origins of the movement were a "systemic conflict with endemic detonator and conjunctural" (Sola-Morales, 2016a). To understand the Mexican case a little better, it its general context might be taken into account: Regarding politics, the country was in the midst of the 2012 electoral process, and Enrique Peña Nieto was running for election as a candidate of the Partido Revolucionario Institucional (PRI), with a corporatist, neoliberal and center-right ideology. In relation to media communication, the country lived a monopoly and a strong lack of pluralism (Candón Mena, 2013; Sosa Plata, 2012).

\#YoSoy132 has authentic democracy as its main demand, which can be translated into the achievement of a series of objectives that the participants claim, and that can be summarized as follows: 1) democratization and transformation of the media, information and dissemination; 2) changes in the educational, scientific and technological model; 3) changes in the neoliberal economic model; 4) changes in the national security model; 5) political transformation and links with social movements; and 6) changes in the health model (Sola-Morales, 2016a).

As for the means of action used by the movement, these are both conventional and unconventional. However, there is a predominance of the latter, such as cyber-activism and videoactivism, mainly with the use of platforms such as YouTube, in addition to other social networks (Facebook and Twitter) and websites or blogs. In this sense, it is a movement that originates through social networks — specifically YouTube — and then comes to the streets with conventional actions such as: demonstrations, "caceroladas", strikes or peaceful takeovers or "manifestos" drafting (Sola-Morales, 2016a). In short, \#YoSoy132 bases its strategies primarily on the following logics: a) propagation of ideas in the network, and b) conflict through mass mobilization. The movement had an especially powerful network operation, to the extent that it managed to establish transnational links with groups of Mexican residents or sympathizers in other countries, who came to form cédulas (resistance groups) and to hold many assemblies in different continents in favor of the movement.

\section{Objectives and research questions}

The main objective of this research is to analyze identity construction through videactivism in \#YoSoy132. To do this, first, the identity features of the movement are described. Second, it is analyzed how the internet and, specifically, YouTube, is transforming social movements, and it is questioned if social media is "determinant" or "instrumental". And third, identity narratives represented through YouTube videos are explored. 
Specifically, this article aims to answer the following research questions:

1. What are the identity features of the movement?

2. Which was the role of YouTube in \#YoSoy132? Were social media "determinant" or simply "instrumental"?

3. What is it to be \#YoSoyl32 in social media? Which identity narratives were represented through YouTube videos?

\section{Methodology}

Given the concern of some researchers about the "persistent divorce" (Cammaerts, 2012, p. 118) between research on social movements from a historical, political or sociological perspective and "communicative" research, this study proposes to articulate both edges of a dialectical way. In this regard, we start from the premise that communication is one of the defining activities of any social movement (Rovira, 2013) and, therefore, it must be analyzed taking into account the interaction with other variables.

Thus, to know the identity features of the movement, in a first phase of this investigation, a systematic analysis of six key observations about \#YoSoyl32 identity processes was carried out. These basic observations have been delimited attending the author's previous work (Sola-Morales, 2016a). Table 1 shows the variables.

Table 1. Variables to Analyze Identity Features of the Movement (Q1)

\begin{tabular}{l}
\hline 1. Nucleus of belonging \\
\hline 2. Main sociodemographic features \\
\hline 4. Forms of leadership \\
\hline 5. Collective identity \\
\hline 6. Relationship with otherness \\
\hline
\end{tabular}

Source: own work.

This design has allowed, in a second stage, to connect these dimensions with the uses of the Internet (role and function of the videos) and with the "determin" or "instrumental" role of social networks. This exploration and description has allowed us to find out if the actions carried out on-line were an "end" in themselves, or if they were a "medium", in the sense that they accompanied other off-line actions, such as demonstrations, assemblies or meetings of any kind. In order to analyze the construction of "mediatic identites", we have used as a reference the previous works by the author (Sola-Morales, 2012; 2013a; 2013b; 2016a; 2016b), and some of the empirical research by Víctor Sampedro (2004a; 2004b). Thus, an analysis instrument was built. 


\section{Analysis instrument}

The qualitative content analysis instrument tool explores: a) what is the role of the selected videos? Are they "intrumental" o "determinant"?, and b) what are the mediatic identities represented in the selected videos?

Table 2. Role of the video, function in the movement (Q2)

1. Birth of the movement

2. Propagation of ideas and values

3. Calls for assemblies or demonstrations

4. Organization or communication of the movement

5. Increment of digital participation

6. Establishment of transnational links

Source: own work

Table 3. Mediatic identities represented in the videos (Q3)

1. Protagonists appearing in the videos: main role, gender and age range

2. Locations where these characters appear

3. Type of identity represented: hegemonic or counter-hegemonic, majority or minority

Source: own work.

It is worth mentioning that investigating the internet uses of the Mexican student movement six years after its implosion is a complex task. This is mainly because there is no detailed record of the key political actions of the movement carried out in the network. In addition, the ideological fragmentation makes thousands of fanpages on Facebook, websites, blogs and Twitters of each of the groups or resistance groups appear, in addition to thousands of videos on YouTube federative or home, made by students or supporters of the movements. However, thanks to the abundant scientific literature and records found on the network, it has been possible to analyze the main uses of YouTube.

\section{Selected corpus}

Given that in the Mexican case videoactivism played a fundamental role in the boom, development and dissemination of the movement, it was decided to pay special attention to the YouTube platform, and to the virals published during May 2012. Specifically, the following five viral videos were analyzed: 1) "131 estudiantes de la Ibero responden" 
["131 students of the Ibero respond"] (R3cr3o, 2012), with 1,241,668 visualizations; 2) "YoSoy132" ["I am 132"] (Yo Soy, 2012), with 457.559; 3) "Manifiesto \#YoSoy132" ["Manifest \#YoSoy132"] (YoSoy132Oficial, 2012), with 388.220; 4) "Luz132" ["Light132"] (Hazte notar, 2012), with 318.598; and 5) "Segundo manifiesto" ["Second Manifesto"], with 162,777.

\section{Results}

\section{Identity features of the movement}

Given that identity categories are understood here as symbolic-narrative artifacts in constant construction and reconstruction (Sola-Morales, 2012; 2013a; 2013b; 2016b), before analyzing the media representation of identity - through YouTube - a brief general description was made of the main identity features of the movement and its main protagonists, that is to say, those that were declared at the beginning by the promoters or spokespersons. For this, the following variables were considered: 1) nucleus of belonging, 2) main sociodemographic features, 3) forms of leadership, 4) interests, 5) collective identity and 6) relationship with otherness.

1) Nucleus of belonging. As far as this variable is concerned, the protagonists belong to the elite. This is because they are, in the first place, university students and, in the second, they have access to internet. These two elements do not match the majority of the Mexican population that has difficulties accessing both education and new technologies'. In fact, only a minority live in the digital sphere (Gómez $\varepsilon$ Treré, 2014). Specifically, some of the actors in the videos were students of the Universidad Iberoamericana, "an elite university where the socio-economic and cultural homogeneity of its student population prevails" (Silva Laya $E$ Jiménez Romero, 2015), and others came from other houses of study. But in any case, all of them belong to "an exclusive sector with access to professional career" (Meneses Rocha, Ortega Gutiérrez, \& Urbina Cortés, 2017, p. 93).

2) Sociodemographic features. Regarding the main sociodemographic features in light of a recent study, they could be described as young people under 30 years of age, of both genders, although with a higher prevalence of female participants. (Meneses Rocha, Ortega Gutiérrez, E Urbina Cortés, 2017, p. 90). Although they are included within the youth variable, it is important to note that these young people are not representative of the entire young Mexican population, which is very heterogeneous and belong to very different socio-economic strata and have quite diverse biographies. In this sense, our observed subjects could be defined as privileged urban youths, regardless of their economic income or their family

México is the country among the members of the Organization for Economic Cooperation and Development (OCDE) where fewer people have completed some degree of higher education. Only $17 \%$ of people aged 25-64 have higher education. 
of origin. In terms of their ideology, in principle the students describe themselves as non-partisan and with a lack of federal affiliation.

3) Forms of Leadership. Although the protagonists that drove the movement were university students, a group that is not representative of all the youth of the country, the forms of leadership used were relational, to the extent that anyone could participate and lead without an existing fixed hierarchy or a vertical structure.

4) Interests. By deepening the identity traits proposed in the manifestos and in the key discourses of the movement it is possible to discern that these are indeterminate, they have a universal scope. These demands not only benefit university students, but citizenship in general and the whole country.

5) Collective identity. Identity ascription is strong, since it is an identity of resistance, which develops a conflictive relationship with otherness. In this case, the fragmentation is geographical since there are groups of sympathizers in different continents. However, the demands are the same for everyone.

6) Relationship with otherness. For the Mexican student movement, the main enemy -which is the expression of otherness - is the Government of Enrique Peña Nieto, as well as the media monopoly and the neoliberal economic model. In this sense, the relationship with the hegemonic power generates a conflicting and antisystemic identity.

\section{Role of YouTube in \#YoSoy132 and mediatic identities represented}

\section{"131 students of the Ibero respond"}

This video starts with archival images of the media coverage of the 2012 protest at the Universidad Iberoamericana, where students are classified as a group of 20 rioters "not young but as 30 or 35 years old" — says the narrator- This is not a video created for propaganda purposes to attract followers or to express the demands of any specific movement or defined in the first instance. At its birth, it was used as an alternative way of expressing the right to reply by a group of students, against the mass media.

In response to the news that appeared in several newspapers of the Organización Editorial Mexicana (OEM) — which headed the covers of all the newspapers of the group, in all the cities of the country, with the headline: "Success of Peña Nieto at the Ibero after orchestrated boycott attempt" - 131 students address the camera in short and medium shots and report the situation on May 14 ${ }^{\text {th }}, 2012$.

The video starts with these words spoken by young people looking at the camera with a serious face: "Dear Joaquín Cowell, Arturo Escobar, Emilio Gamboa, as well as 
media of dubious neutrality, we use our right of reply to disprove: We are students of the Ibero, not acarreados [mass of people without own ideas], not porros [shock and violent groups] and no one trained us at all". Then the 131, one by one, or in small groups indicate their name and registration number with the university card in its hands. This video was viewed by 21,747 users in the six hours after publication (Candón Mena, 2013).

\section{“I am 132"}

"I am 132" is a video that was born in order to express the demands of a consolidated social movement. In this case, the video is in itself the embryo of the movement and marks its birth. This video gives a strong power to the message that is the following:

Your country and mine is suffering; we live submerged in a deep crisis; the heartrending violence, the enormous poverty, the lack of justice; social inequality, limited access to education and an absent democracy that afflicts us every day. There are bullets left over, misery is left and conscience is lacking. We will not support this situation anymore. We unite our voices to demand our right to impartial, plural and transparent information. We demand real competition in the media sector, we demand the transmission of the debate in national broadcasters, through the two networks of greater reach and greater audience. As a movement we demand that all candidates for the presidency commit themselves to end the television duopoly that prevents access to effective information. We demand a fair and transparent electoral process. For this we request support for the press and the different international organizations. Today the young people of Mexico have lit a light in the public life of the country. Let's assume this historical moment with courage, responsibility and integrity. Do not wait any longer. Let's not walk anymore. Let's unite, let's organize. Mexico needs us. There is no citizenship without freedom of expression. For them we show our strongest solidarity with all those who have seen their voices silenced and with the causes defended by social movements in favor of justice. We join the voice of the movement against Enrique Peña Nieto, the people of Atenco, the relatives of the victims of feminicide. The students and youth demonstrations throughout the country that have been repressed, the indigenous people in resistance, the journalists reached by violence, the workers, workers and peasants silenced and exploited, and sexual diversity silenced by obscurantism. For an authentic democracy! I am 132!

\section{“Manifesto \#YoSoy132"}

In this video, a direct proclamation is made about the demands of the movement: "the right to information and the right to freedom of expression". The different narrators (both women and men voices in off, and characters looking at camera): a) describe the bad situation that is experienced in the country, in general, while they are showing file images taken from the internet, of violent situations; b) denounce the monopoly of 
media conglomerates Televisa and Televisión Azteca; c) describe what the movement is like — no party position, made up by citizens —, what its proclamations are —authentic democracy — and what its main demands are — democratizing the media-; c) demand changes; d) demand the participation of young people and students; and e) show solidarity with different minority groups.

Three types of images are conjugated in this video: Images of locations on the street that show scenes of poverty and conflict; planes of specific characters who look at the camera and express their opinions; and archive images of the 1968 student movement in black and white with background music, followed by images of more recent manifestations in which a narrator addresses the students again, to join the request. To finish, different people in work environments or on the street go to the camera, in short shots, and say "I am 132". This video, in addition to functioning as a denunciation, a manifesto and a declaration of intentions, has a marked identity tone, since it aims to generate empathy with the people, the oppressed, citizens without a name and without presence in the mass media.

\section{"Light 132"}

This denouncing video collects archive images of several violent events in the History of Mexico that had dubious media coverage. It is articulated with phrases and background music. The altercations occurred in 1968, when 300 students died at the hands of the police; the confrontations with the police in 1971 when 120 people died; the 1988 elections with their respective demonstrations against electoral fraud; the 1994 murder of President Luis Donaldo Colosio; the White Water Tragedy in 1995 where 17 peasants were killed and the riots of Atenco, where there were two deaths, 201 injured and 23 sexually abused women... Finally, the following message is sent: "For decades the PRI has agreed that you are an apathetic. Apathetic does not question anything. Apathetic bends, apathetic does not vote". Then there are images of demonstrations against Televisa and images of supporters of the \#YoSoy132 movement.

\section{"Second Manifesto"}

Second manifesto reproduces a very similar logic to that of the first manifesto, with the appearance, again, of university students who look at the camera and declare frontally what it is to be 132, initiating their speeches with the simple phrase "We are...". Thus, in a first part of the video, the movement is briefly presented and then characters begin to enumerate the characteristics of \#YoSoyl32: 
We are children of the massacres, of student repressions, of dirty war, of rampant impunity, of economic crises, of ideological and material domination, of a way of thinking and a way of living, of senseless violence, of an abandoned field and unworthy working conditions, of deep corruption, we are children of a new Mexico that screams: Stop! Never more! We are those who have found new ways of accessing reality and new ways of acting. We are not only those who can study, but also those who yearn to study and do not have the necessary conditions, those who studied will continue to do so to be better citizens and make this a better country [...] We are Mexicans without distinction, students that invite society to join our cause.

In short, the analyzed videos have five main roles: 1) Show the right to replicate to "falsehoods" and accusations made against the protagonists in mass media, as is the case of "131 students of the Ibero respond"; 2) Express the demands of the movement, as happens in the five videos analyzed; 3) Describe the identity of the movement and show the cohesion of its members: express what it is to be \# YoSoyl32 versus what it is not to be, as "I am 132" or "Second Manifesto"; 4) Claim the participation of citizens and young people, as in all videos analyzed; and 5) Report the violence and conflict that have given rise to the development of the movement, as especially occurs in "Light 132" or "Manifesto \# YoSoy132".

\section{Discussion}

A "recent social movement" in the digital era should be characterized by its network organization. It should have horizontal forms of communication, no hierarchies, and favor new forms of participation and virtual interaction. But what happens with the \#YoSoyl32 movement?

When analyzing the selected videos, it was observed that the role of most of the characters that appeared was that of young university students, with a marked critical awareness. This is the case of the "131 students of the Ibero respond", students of the Iberoamericana University, who look at the camera and declare that they are students, or the case of "I am 132", a video where students from nine different universities of the country appear also looking at the camera and expressing the main demands of the movement. In these two videos the university students are clearly the protagonists since their presence and voices fill the whole plane (medium or general) and they are the only characters that appear.

However, the characters in "Manifiesto \#YoSoy132" or "Light 132" are much more heterogeneous and have different roles. In "Manifiesto \# YoSoy132" archival images of people in a disadvantaged situation are presented: poor children in the street, protesters, adults searching the garbage, deaths and victims of police violence, relatives of the victims of San Salvador de Atenco, policemen carrying bloody bodies, actors 
and street dancers, beggars... Then the protagonists and narrators appear, looking at the camera. The narrator — who alternates female and male voices — calls himself "the young people" or "the united students of this country". However, the characters involved are people both young and old, women and men, workers and families, couples or groups of friends who approach the camera expressing what it means to be \#YoSoyl32 with phrases like: "We are a movement alien to any partisan structure and constituted by citizens and as such [...] we do not express any support to any candidate, political party, but we respect the plurality and diversity of the members of this movement", or "we are a movement concerned about democratization from the country". In "Light 132", the characters that appear are victims and oppressed, on the one hand, and police and politicians - who claim to use force against the population out of necessity —, on the other. Also, as in "Manifiesto \#YoSoy132", the protesters are present among the represented characters.

Regarding the gender of the characters that appear in the analyzed videos, although in "131 students of the Ibero respond" or "I am 132" more women than men participate ( 81 versus 49 in the first, 8 versus 5 in the second), it can not be said that there is more female representation, since in "Second Manifesto", there are more men than women (10 versus 5) and in "Manifesto \# YoSoy132" or "Light 132" both genders appear indistinctly.

When observing the age range, it was possible to conclude that the majority of the videos were done by young people between 18 and 30 years old. Thus in "131 students of the Ibero respond", "I am 132", or "Second Manifesto" they are the only protagonists. However, this trend is not general since in "Manifesto \#YoSoyl32" or "Light132" in addition to the young people, people of all ages are also represented.

In relation to the place where these characters appear we can distinguish different locations: a) private spaces, as in the case of the video "131 students of the Ibero respond", where students appear in their rooms or rooms of houses — probably family houses or shared flats-; b) public spaces, such as streets or squares where students approach the camera, as in the case of "Manifiesto \#YoSoy132", for example, or c) built spaces: studio sets with a black background, where the place lacks importance and the fundamental value is the character and, above all, the message, as is the case of "I am 132" or "Second Manifesto".

In addition, there is a clear difference between two types of represented scenarios: 1) safe scenarios, those that are calm and comfortable, where the protagonists and students appear, like their residences of upper-middle class, work centers or streets, as in "131 students of the Ibero respond", "I am 132" or "Second manifesto", against 2) scenarios of conflict, those where violence, rot, dirt, death or misery are the protagonists, as is the case of "Manifesto \#YoSoy132" or "Light 132". 
Regarding the type of identity represented, different tendencies can be observed. On the one hand, the classic dichotomy between "We" (good) and "They" (bad) is found. As Teun Van Dijk (2009) has pointed out, the polarization between 'we' and 'them' is a mark that differentiates the in-group from the outgroup. Thus the pronoun 'we' or 'us' refers to the group of belonging and the 'they' or 'them' helps us to discover which is the exclusion group is (Sola-Morales, 2012, p. 222).

In this case, it is a "we" that fights for authentic democracy and that includes young people, students, citizens, and the oppressed. And by the other side, it is facing a "them" that destroys and prevents said democracy in a dark, violent way, that is represented by policemen, Enrique Peña Nieto, PRI politicians, large corporations and the media, such as Televisa and Televisión Azteca, that conceal the truth and manipulate it. For example, in "I Am 132" the 'us' is clearly stated: "We will not stand anymore", "we now unite our voices" or "we demand". Or in "Manifesto \#YoSoyl32": "We, the Youth", "it's time for us to fight for our country".

On the other hand, there is also a dichotomy between those who narrate the video, who are not in a situation of vulnerability, and those with whom the movement is in solidarity, that are the oppressed. The first are clearly privileged. In the case of "131 students of the Ibero respond", elite students take part, with access to the Internet and a family computer or their own with Webcams, mobile phones or home cameras, with which they speak from the comfort of their homes. In the cases of "I am 132" and "Second Manifest", students with audiovisual resources - cameras and sets to shoot on - and the ability to build an elaborate speech, an aesthetic and a staged work, and even a special wardrobe, take part. In "I am 132", everyone wears a shirt with the slogan \#YoSoyl32.

The second are all those listed collectives that are clearly counter-hegemonic. For example, in "I am 132": all those whose voices have been silenced, the social movements for justice, the student and youth demonstrations, the movement against Enrique Peña Nieto, the people of Atenco, the relatives of feminicide victims, indigenous people in resistance, journalists reached by violence, silenced and exploited works and peasants, silenced sexual diversity. In a very similar way in "Manifiesto \#YoSoy132", the union with "all the oppressed" is indicated (again): the movement against Enrique Peña Nieto, victims of feminicide, murdered journalists, oppressed demonstrators, persecuted sexual minorities, settlers, exploited workers, victims of Atenco, students in mobilization, movements for peace, with justice and dignity, relatives of feminicide victims in Ciudad Juárez and in other regions, indigenous people in resistance, sexual minorities silenced by obscurantism. In this sense, it is an identity of resistance in which the identification with the other, the oppressed or the disadvantaged, is fundamental. 
Likewise, it is necessary to indicate that it is a very aesthetic identity insofar as the discourse analyzed and the attitudes of the main protagonists have a certain relationship with advertising communication. For example, "Second Manifesto" uses slogans such as: "This movement is nourished by ties of solidarity among peers, equality among citizens, fraternity between brothers, trust between colleagues, love between comrades, respect between human beings". Or in "I am 132", students make small gestures such as raising their fist or other symbols of resistance as they look at the camera and claim their demands.

In short, the videos analyzed tend to build a counter-hegemonic identity. This does not associate with minorities, on the contrary, it has to do with the majority — still silent - that make up society or Mexican citizenship in general. And so it is recorded in videos as "Manifesto \#YoSoy132". The universality of the movement is expressed with phrases like: "[YoSoy132] is an inclusive movement that does not represent a single university", but rather aims at "people who join this cause", we have the "need to empower the common citizen", the "citizenship [should be] conscious and participatory", it is necessary to become a "critical citizen".

\section{Conclusions}

Regarding the first research question Q1: What are the main identity features of \#YoSoyl32? It can be concluded that from its birth and during its development, the Mexican movement marked its partisan disaffiliation. It was clearly expressed that the movement had no relation with the houses of studies, neither with the IberoAmerican University nor with the Tecnológico de Monterrey or with others. As for the identity construction, a strong identity, of resistance was observed. In both cases, beyond the first "student" impulse the messages developed with a universality scope: the struggle of the oppressed, the citizens or people against those who dominate, exercise violence, manipulate or profit at the expense of the poor.

In relation to the second question: Which was the role of YouTube in \#YoSoyl32 digital partipation and youth engagement? Were social media "determinant" or simply "instrumental"? Regarding the use of the internet and social media, in the Mexican case these were decisive. Namely, the \#YoSoy132 movement was born in internet. Following the video "I am 131", the critical students of the country decided that it was time to raise their voices against the Government, and position in the public debate a series of slogans and proclamations in favor of a "real democracy". It can be concluded that the role of YouTube was fundamental in that social movement, since the videos analyzed were foundational, gave it name and identity and, above all, these videos made mass publicity in the network. Thus, social media were determinant. 
The main demands, traits and values of the movement and its members were shown in these videos, and the world was shown what it was to be \#YoSoy132. Specifically, the analyzed videos had five roles: 1) Demonstrate the right to replicate the protagonists in front of mass media; 2) Express the demands of the movement; 3) Describe the identity of the movement; 4) Claim the participation of citizens and young people; and 5) Report the violence and the conflict that the country experienced.

In relation to the research question Q3 ("What is it to be \#YoSoyl32 in social media? Which identity narratives were represented through YouTube?"), it can be concluded, firstly, that being \#YoSoyl32 goes far beyond being young, student or belonging to a specific university. While many of the videos are carried out by young university students and they were the driving force of the movement, they manifest the importance of solidarity with the "other". That means with the oppressed and the disadvantaged. This was the main identity sign in fact. And secondly, that the movement is universal because people of all ages, genders, ethnic groups and ideological conditions have a place. The message was targeted particularly at persons at risk or discrimination, as well as at feminicide victims, murdered journalist, pursued and muted sexual minorities, original settlers, working-class, poor and exploited workers.

In this regard, a resistant identity was developed in a conflictive and anti-systemic relation with alterity. Here, the scenario is not occupied by a single subject or specific group of people well defined or delimited. On the contrary, the space is occupied by a group of diverse actors with a set of common goals. This diffuse matrix distances itself from other classical typologies such as that of workers movements, for instance. Indeed, it is precisely that logic of collective action which transcends the production field and opens new questions more related to the socio-cultural. Given that it is a resistance identity, its main axis remains in conflict or confrontation. The opposition is between those who define themselves as "132" and a set of "identified adversaries" — as Touraine might say — that are the neoliberal system and the people who perpetuate it (Government and businessmen).

\section{References}

Banaji, S., \& Buckingham, D. (2010). Young people, the Internet, and civic participation: an overview of key findings from the CivicWeb Project. International Journal of Learning and Media, 2(1), 15-24.

Barassi, V., \& Treré, E. (2012). Does Web 3.0 come after Web 2.0? Deconstructing theoretical assumptions through practice. New Media \& Society, 14(8), 1269-1285.

Bennett, W. L., \& Segerberg, A. (2012). The logic of connective action. Information, Communication E Society, 15(5), 739-768. http://dx.doi.org/10.1080/1369118X.2012.670661 
Bennett, W. L., E Segerberg, A. (2013). The logic of Connective Action. Digital Media and the Personalization of Contentious Politics. Cambridge University Press.

Breuer, A. (2012). The Role of Social Media in Mobilizing Political Protest: Evidence from the Tunisian Revolution. German Development Institute Discussion Paper No. 10/2012. Deutsches Institut für Entwicklungspolitik (DIE). http://dx.doi.org/10.2139/ssrn.2179030

Brisset, D. (2011). Los medios digitales de comunicación: experiencias de activismo audiovisual. Telos: Cuadernos de comunicación e innovación, 88, 24-36.

Chadwick, A. (2013). The Hybrid Media System: Politics and Power. Oxford Press.

Candón Mena, J. (2013). Movimientos por la democratización de la comunicación: los casos del 15-M y \#YOSOY132. Razón y Palabra, 82, 1-21.

Cammaerts, B. (2012). Protests logics and the mediation opportunity structure. European Journal of Communication, 27(2), 117-134.

Castells, M. (2009). Comunicación y poder. Alianza.

Carty V., E Reynoso Barrón F. G. (2019). Social Movements and New Technology: The Dynamics of Cyber Activism in the Digital Age. En B. Berberoglu (ed.), The Palgrave Handbook of Social Movements, Revolution, and Social Transformation (pp. 373-397). Palgrave Macmillan. http://dx.doi. org/10.1007/978-3-319-92354-3_16

Chamberlain, K. (2004). Redefining cyberactivism: The future of online project. Review of Communication, 4(3-4), 139-146. http://dx.doi.org/10.1080/1535859042000289397

Colombo Villarrasa, C. (2007). E-participación. Las tic al servicio de la innovación democrática. Universitat Oberta de Catalunya.

Coombs, A. (2009). How Cyber-activism Changed the World. Griffith Review, 24, 183-189.

Cotarelo, R., E Crespo, I. (comp.) (2012). La comunicación política y las nuevas tecnologías. Catarata.

Dodaro, C. (2009). El videoactivismo. Experiencias de resistencia cultural y política en la Argentina de los años noventa. Palabra Clave, 12(2), 235-244.

Earl, J., y Kimport, K. (2011). Digitally Enabled Social Change. Activism in the Internet Age. The mIT Press.

García Galera, M. C., y Hurtado, M. H. (2013). Redes sociales, un medio para la movilización juvenil. Zer: Revista de Estudios de Comunicación, 17(34), 111-125.

Gerbaudo, P. (2012). Tweets and the streets. Social media and contemporary activism. Pluto Press.

Gerodimos, R. (2010). New Media, New Citizens: The Terms and Conditions of Online Youth Civic Engagement (tesis de doctorado). Bournemouth University, UK.

Gladwell, M. (2010). Small Change: Why the Revolution will not be Tweeted. New Yorker. Recuperado de https://www.newyorker.com/magazine/2010/10/04/small-change-malcolmgladwell?verso $=$ true.

Gómez García, R., y Treré, E. (2014). The \#YoSoy 132 movement and the struggle for media democratization in Mexico. Convergence: The International Journal of Research into New Media Technologies, 20(4), 496-510. 
Hacker, K. L., E Van Dijk, J. (eds.) (2000). Digital democracy: Issues of theory and practice. Sage.

Hazte notar (2012, junio 13). \#Luz132. Youtube. Recuperado de https://www.youtube.com/ watch?v $=$ cOh4CmjLG10

Hussain, M., \& Howard, P. (2013). What Best Explains Successful Protest Cascades? ICTs and the Fyzzy Causes of the Arab Spring. International Studies Review. Special Issue: International Relationships in the Information Age, 15(1), 48-66.

Juris, J. (2012). Reflections on \#Occupy Everywhere: Socialmedia, public space, and emerging logics of aggregation. American Ethnologist, 39(2), 259-279.

Karakaya, R. (2005). The Internet and the Political Participation. European Journal of Communication, 20(4), 435-559.

Khamis, S. (2017). Revisiting Cyberactivism Six Years after the Arab Spring: Potentials, Limitations and Future Prospects. En N. Lenze, C. Schriwer y Z. Jalil (eds.), Media in the Middle East (pp. 3-19).. Palgrave Macmillan.

Khamis S., E Alwadi N. (2015). Cyberactivism and Ongoing Political Transformation. En I. Epstein (Eds.). The Whole World is Texting. Pittsburgh Studies in Comparative and International Education. Sense Publishers. http://dx.doi.org/10.1007/978-94-6300-055-0_3

Mateos, C., y Gaona, C. (2015). Constantes del videoactivismo en la producción audiovisual. Rastreo histórico (1917-2014) y puntualizaciones para una definición. En F. Sierra y D. Montero (eds.), Videoactivismo y movimientos sociales. Teoría y praxis de las multitudes conectadas (pp. 106-137). Gedisa.

Mateos, C., E Rajas, M. (2014). Videoactivismo, la resistencia política cámara en mano: concepto y rasgos. En J. Sierra Sánchez y F. García García (eds.), Tecnología y Narrativa audiovisual (pp. 805-838). Fragua.

Mattoni, A. (2012). Media practices and protest politics: How precarious workers mobilise. Ashgate.

McCaughey, M. (ed.) (2014). Cyberactivism on the Participatory Web. Routledge.

McCaughley, M., E Ayers, M. D. (2003). Cyberactivism: Online Activism in Theory and Practice. Routledge.

McCurdy, P. (2011). Theorizing activist's 'lay theories of media': A case study of the Dissent! network at the 2005 G8 Summit. International Journal of Communication, 5, 619-638.

Meneses Rocha, M. E., Ortega Gutiérrez, E., E Urbina Cortés, G. (2017). Youth and Political Participation. \#YoSoy 132 and the struggle for Freedom of Expression in Mexico. Communication E Society, 30(1), 87-103.

Montero Sánchez, D., E Candón Mena, J. I. (2015). Sobre las imágenes del 15M. El videoactivismo como experimentación cultural y polític. En F. Sierra (ed.), Videoactivismo y movimientos sociales. Teoría y praxis de las multitudes conectadas (pp. 332-357). Gedisa.

Montero Sánchez, D., y Sierra Caballero, F. (2017). Videoactivismo y apropiación de las tecnologías. El caso de 15M. Chasqui: revista latinoamericana de comunicación, 134, 263-276.

Mxahoraonunca (2012, junio 10). 2do Manifiesto \#YoSoy 132. Youtube. Recuperado de https:// www.youtube.com/watch?v=0GKzsDuhC-O 
R3CR3O (2012, mayo 14). 131 Alumnos de la Ibero responden. Youtube. Recuperado de https:// www.youtube.. m $/$ watch?v $=$ P7XbocXsFkIElist $=$ PL9EAA7FA834BF7FCB

Rovira, G. (2013). Activismo mediático y criminalización de la protesta: medios y movimientos sociales en México. Convergencia, 20(61), 35-60.

Rudenko, V. N. (2009). La ciberrepública y el futuro de la democracia directa. Contribuciones desde Coatepec, 16, 165-176.

Sabariego, J. (2017). Tecnopolítica y Recientes Movimientos Sociales Globales. En B. de Sousa Santos y J. M. Mendes, Demodiversidad. Imaginar nuevas posibilidades democráticas (pp. 391-416). Akal.

Sabariego, J. (2018). Recientes Movimientos Sociales Globales y tecnopolítica desde las Epistemologías del Sur. Pensamiento al margen. Revista digital, 8, 74-89.

Sampedro, V. (ed.) (2011). Cibercampaña. Cauces y diques para la participación. Las elecciones generales de 2008 y su proyección tecnopolítica. Universidad Complutense de Madrid.

Sampedro, V. F. (2004a). Identidades mediáticas e identificaciones mediatizadas. Visibilidad y reconocimiento identitario en los medios de comunicación. Revista CIDOB d'Afers Internacionals, 66-67, 135-149.

Sampedro, V. F. (2004b). Identidades mediáticas. La lógica del régimen de visibilidad contemporánea. Sphera Pública, 4, 17-35.

Sandoval-Almazan, R., E Gil-García, J. R. (2014). Towards cyberactibism 2.0.? Understanding the use of social media and other information Technologies for political activismo and social movements. Government Information Quaterly, 31(3), 365-378. http://dx.doi.org/10.1016/j. giq.2013.10.016

Sierra, F. (2018). Ciberactivismo y movimientos sociales. El espacio público oposicional en la tecnopolítica contemporánea. Revista Latina de Comunicación Social, 73, 980-990.

Sierra, F., E Gravante, T. (2017). Tecnopolítica en América Latina y el Caribe. Comunicación Social Ediciones y Publicaciones.

Sierra, F., E Montero, D. (2015). Introducción. En F. Sierra y D. Montero (eds.), Videoactivismo y movimientos sociales. Teoría y praxis de las multitudes conectadas Barcelona, España: Gedisa.

Sierra, F., E Montero, D. (2016). Videoactivismo y nuevos movimientos urbanos en España. Andamios. Revista de Investigación Social, 29(12). 161 182.

Silva Laya, Y. M., E Jiménez Romero, A. (2015). Estudiantes de contextos vulnerables en una universidad de élite. Revista de la Educación Superior, 16(3), 95-119.

Sirkkunen, E., E Kotilainen, S. (Eds.). (2004). Towards Active Citizenship on the Net. Possibilities of Citizen Oriented Communication: Case Studies from Finland. University of Tampere.

Sola-Morales, S. (2012a). ¿Víctima o heroína? Un análisis crítico de los blogs 'Mujeres' y 'En Femenino'. Discurso E Sociedad, 6(4), 815-849. Recuperado de http://www.dissoc.org/ediciones/ v06n04/DS6(4)Sola.html.

Sola Morales, S. (2012b). La dialéctica entre las narrativas mediáticas y los procesos de identificación (tesis de doctorado). Departamento de Medios, Comunicación y Cultura, Universidad Autónoma de Barcelona. Barcelona, España. 
Sola-Morales, S. (2013a). Hacia una tipología de narrativas mediáticas identitarias. Sphera Pública, 13(2), 30-48. Recuperado de http://sphera.ucam.edu/index.php/sphera-01/article/ view/150/156.

Sola Morales, S. (2013b). Mediatic Narratives and Identification processes. A theoretical and methodological approach. Revista Orbis, 24(8), 36-50. Recuperado de http://www.revistaorbis. org.ve

Sola-Morales, S. (2016a). Las redes sociales y los nuevos movimientos estudiantiles latinoamericanos. La Primavera chilena y el YoSoy 132. IC. Revista Científica de Información y Comunicación, 13, 151-193. http://dx.doi.org/10.12795/IC.2016.i01.05

Sola-Morales, S. (2016b). Comunicación mediática y procesos de identificación: una construcción dramática y ritual. Athenea Digital, 16(2), 247-269. http://dx.doi.org/10.5565/rev/athenea. 1448

Sosa Plata, G. (2012). \#YoSoy 132: jóvenes frente a las redes sociales y la democratización de los medios de comunicación. En C. Arango, J. Bañuelos, P. Ricaurte y G. Sosa Plata (ed.), Esfera pública y tecnologías de la información y la comunicación (pp. 80-88). México: Instituto Electoral del Distrito Federal.

Touraine, A. (2015). A Method for Studying Social Actors. Journal of World Systems Research, 6(3), 900-918

Treré, E. (2012). Social movements as information ecologies: Exploring the coevolution of multiple Internet technologies for activismo. International Journal of Communication, 6, 2359 2377. Recuperado de http://ijoc.org/index.php/ijoc/article/view/1681/797.

Treré, E. (2015). Ecología del videoactivismo contemporáneo en México: alcances y limitaciones de las prácticas de resistencia en las redes digitales. En F. Sierra y D. Montero (eds.). Videoactivismo y movimientos sociales (pp. 167-187). Gedisa.

Ugarte, D. (2007). El poder de las redes. Ediciones El Cobre.

Vaast, E., Safadi, H., Lapointe, L., y Negoita, B. (2017). Social media affordances for connective action: an examination of microblogging use during the Gulf of Mexico oil spill. Journal of MIS Quarterly, 41(4), 1179-1205.

Van Dijk, T. A. (2009). Discurso y poder. Gedisa.

Ward, J. (2005). An opportunity for engagement in cyberspace: Political youth Web sites during the 2004 European Parliament election campaign. Information Polity, 10(3), 233-246.

Welp, Y. (2015). Cuando todo lo sólido se desvanece en Twitter. Análisis del movimiento social en \#YoSoy 132. PosData, 20(2), 417-439.

Weyland, K. (2012). The Arab Spring: Why the Surprising Similarities with the Revolutionary Wave of 1848?. Perspectives on Politics, 10, 917-934. https://doi.org/10.1017/S1537592712002873

YoSoy 132Oficial (2012, mayo 29). Manifiesto \#YoSoy 132. Youtube. Recuperado de https://www. youtube.com/watch?v=igxPudjF6nU

Yo Soy (2012, mayo 29). YoSoy 132. Youtube. Recuperado de https://www.youtube.com/ watch?v $=$ t6LgxA-7FiM 